\title{
Growth and Productivity of Four Cassava Cultivars on Several Levels of Mixed Fertilizers
}

\author{
Sri Wahyuningsih ${ }^{1}$, Febria Cahya Indriani ${ }^{1}$, Joko Restuono ${ }^{1}$, Kartika Noerwijati ${ }^{1, *}$, \\ Abdullah Taufiq ${ }^{1}$, Yuliantoro Baliadi ${ }^{1}$, Rohmad Budiono ${ }^{2}$, Nguyen Van Minh ${ }^{3}$ and \\ Peeyush Soni ${ }^{4}$
}

\begin{abstract}
${ }^{1}$ Indonesian Legumes and Tuber Crops Research Institute, Jl. Raya Kendalpayak km 8, Malang 65101, East Java, Indonesia; ${ }^{2}$ East Java Assessment Institute of Agriculture Technology, Jl.Raya Karangploso km 4 PO BOX 188, Malang,65101, East Java, Indonesia; ${ }^{3}$ Faculty of Agriculture and Forestry, Tay Nguyen University, 567 Le Duan, Ea Tam, Thanh pho Buon Ma Thuot, Dak Lak 630000, Vietnam; ${ }^{4}$ Department of Agricultural and Food Engineering, Indian Institute of Technology Kharagpur, Kharagpur, West Bengal, India - 721302;
\end{abstract}

Received: May, 5, 2021; Revised: August, 20, 2021; Accepted Oct, 16, 2021

\begin{abstract}
Cassava is responsive to fertilization, and it is one of the important factors for high productivity. Root formation needs sufficient Phosphorus (P) and Potassium (K) nutrients, and adequate nutrients uptake increases root weight and starch content. However, the optimum effect of $\mathrm{P}$ and $\mathrm{K}$ fertilization should be balanced with Nitrogen $(\mathrm{N})$ fertilization. The objective of the study was to determine the effect of mixed (inorganic and organic) fertilizers doses on the growth and yield of several cassava cultivars grown in Pati district, Central Java, Indonesia. The experiment was carried out during planting season in 2018. Four cassava cultivars (Litbang UK 2, UK 1 Agritan, Malang 4, and UJ 5) were tested under five doses of mixed fertilization. The split-plot design with three replicates was used in this experiment, where fertilizations as the main plot and cultivars as the subplot. The results showed that mixed fertilization had no significant effect, while the cultivars had a significant effect on growth and yield parameters as well as starch content. No significant interaction effect of the two factors, except in plant height.
\end{abstract}

Keywords: Environmentally-friendly fertilization, Improving cassava production, Optimal fertilizer, Prevent nutrient loss, Rational and balanced fertilization, Root yield, Soil fertility, Starch content

\section{Introduction}

Central Java Province contributes $15.70 \%$ of the cassava (Manihot esculenta Crantz) production in Indonesia. Pati District, Central Java, Indonesia is one of the highest cassava producers among 12 other districts with a planting area of 20.000 ha and productivity of 43.55 $\mathrm{t} \mathrm{ha}^{-1}$. In this district, cassava is a commodity that attracts many farmers, and has become the main crop in their farming. So that, cassava production in Pati District in the period of 2011 to 2015 increased by $9.7 \%$ each year (BPS Jawa Tengah, 2016). The appeal of cassava is triggered by the increasing demand for industrial raw materials.

The majority of cassava in Indonesia is grown on dry land with marginal soil fertility, and hence fertilization plays an important role in cassava cultivation. Several Inorganic Compound (Nitrogen, Phosphorus, and Potassium - NPK) fertilizers grades commonly used for food crops are 15-15-15, 20-10-10, and 30-6-8 (Budiono et al. 2019). Cassava plants are known to be very responsive to fertilization (Howeler, 2017). Increasing cassava productiveness due to NPK fertilization is well reported by Biratu et al. (2018). In the soil with low fertility, high rate of inorganic fertilizers are reqiured (Budiono et al., 2021; Macaloua et al., 2018). Agronomic research is needed to significantly increase the cassava yield through optimal fertilizer application (Ezui et al., 2016).

Cassava absorbs potassium $(\mathrm{K})$ nutrients in high amount, even higher than N. For producing $30 \mathrm{t} \mathrm{ha}^{-1}$, cassava uptake $147.6 \mathrm{~kg} \mathrm{~N}, 47.4 \mathrm{~kg} \mathrm{P}_{2} \mathrm{O}_{5}$, and $179.4 \mathrm{~kg}$ $\mathrm{K}_{2} \mathrm{O}$. Potassium $(\mathrm{K})$ has an important role in synthesis and accumulation of starch in cassava root (Fernandez et al., 2017). However, imbalance fertilization hampered productivity and profitability (Hiironen and Riekkinen, 2016). Imbalance fertilization will also increase nutrient loss (Van der Velde et al., 2014), and consequently degrade soil fertility (Adinurani et al. 2021, Li et al., 2013), as well as pollute the environment (Muhammad et al., 2021; Utami et al. 2020). Cassava more response to inorganic fertilizer when combined with organic fertilizer (Biratu et al., 2018). Badewa et al. (2020) recommend to use $100 \mathrm{~kg} \mathrm{~N}-22 \mathrm{~kg} \mathrm{P}-83 \mathrm{~kg} \mathrm{~K} \mathrm{ha}^{-1}$ combined with $2.4 \mathrm{t} \mathrm{ha}^{-1}$ chicken manure to increase cassava yield. Optimum NPK fertilizer dosage varies among cultivar and environment. Wahyuningsih and Sutrisno (2019) found that to attain yield of $33 \mathrm{t} \mathrm{ha}^{-1}$, Malang 4 cultivar grown under young teak stands needs fertilization of $125 \mathrm{~kg}$ Urea $\mathrm{ha}^{-1}+150 \mathrm{~kg} \mathrm{SP}_{6} \mathrm{ha}^{-1}+100 \mathrm{~kg} \mathrm{KCl} \mathrm{ha}^{-1}$. Noerwijati and Budiono (2015) found different yield in different altitude with same fertilization at rates of $200 \mathrm{~kg} \mathrm{ha}^{-1}$ Urea +100 $\mathrm{kg} \mathrm{ha}^{-1} \mathrm{SP} 36+100 \mathrm{~kg} \mathrm{ha}^{-1} \mathrm{KCl}$, where the higher yield of

\footnotetext{
*Corresponding author e-mail: tika_iletri@yahoo.com
} 
$54.84 \mathrm{t} \mathrm{ha}^{-1}$ attained at altitude of $80 \mathrm{~m}$ a.s.l., followed at $530 \mathrm{~m}$ a.s.l. (37.08 $\mathrm{t} \mathrm{ha}^{-1}$ ), and $7.79 \mathrm{t} \mathrm{ha}^{-1}$ at $800 \mathrm{~m}$ a.s.l.

The study was aimed to determine optimum dose of mixed (inorganic and organic) fertilizers on the growth and yield of several improved-cassava cultivars grown in Pati district, Central Java, Indonesia.

\section{Materials and Methods}

\subsection{Experiment site}

The field experiment was carried out during planting season of 2018 in Pati district, Central Java, Indonesia. Soil in the study site is acidic, but contains very low Al. The soil has very low organic matter, $\mathrm{N}$, and $\mathrm{Mg}$ content, low Ca content, and medium available $\mathrm{P}$, but high exchangeable K (Table 1).

Table 1. Soil properties in the experiment site.

\begin{tabular}{|c|c|c|c|}
\hline Soil properties & Methods & Value & Criteria $^{1)}$ \\
\hline $\mathrm{pH}-\mathrm{H}_{2} \mathrm{O}$ & $1: 5$ (soil : $\mathrm{H}_{2} \mathrm{O}$ ) & 4.68 & $\mathrm{~L}$ \\
\hline C-organic (\%) & Walkley \& Black & 1.21 & VL \\
\hline N-total (\%) & Kjedahl & 0.06 & VL \\
\hline $\mathrm{P}_{2} \mathrm{O}_{5}\left(\mathrm{mg} \mathrm{kg}^{-1}\right)$ & Bray-1 & 13.6 & M \\
\hline $\begin{array}{l}\text { Exchangeable } \mathrm{K} \\
\left(\mathrm{cmol}^{+} \mathrm{kg}^{-1}\right)\end{array}$ & $1 \mathrm{~N} \mathrm{NH}_{4} \mathrm{OAc} \mathrm{pH} 7.07$ & 0.24 & $\mathrm{H}$ \\
\hline $\begin{array}{l}\text { Exchangeable Ca } \\
\left(\mathrm{cmol}^{+} \mathrm{kg}^{-1}\right)\end{array}$ & $1 \mathrm{~N} \mathrm{NH}_{4} \mathrm{OAc} \mathrm{pH} 7.07$ & 1.08 & $\mathrm{~L}$ \\
\hline $\begin{array}{l}\text { Exchangeable } \mathrm{Mg} \\
\left(\mathrm{cmol}^{+} \mathrm{kg}^{-1}\right)\end{array}$ & $1 \mathrm{~N} \mathrm{NH}_{4} \mathrm{OAc} \mathrm{pH} 7.07$ & 0.05 & VL \\
\hline $\begin{array}{l}\text { Exchangeable Al } \\
\left(\mathrm{cmol}^{+} \mathrm{kg}^{-1}\right)\end{array}$ & $1 \mathrm{~N} \mathrm{KCl}$ & 3.39 & VL \\
\hline
\end{tabular}

${ }^{1)} \mathrm{L}=$ low, $\mathrm{VL}=$ very low, $\mathrm{M}=$ medium, $\mathrm{H}=$ high according to Howeler (2002; 2014), Howeler et al. (2019).

\subsection{Treatment and experimental design}

The experiment consisted of two factors which were laid out in a split-plot design, three replicates. The main plot was five fertilizer levels, namely $\mathrm{P}_{1}: 275 \mathrm{~N}+45 \mathrm{P}_{2} \mathrm{O}_{5}$ $+45 \mathrm{~K}_{2} \mathrm{O} \mathrm{kg} \mathrm{ha}{ }^{-1}$ (farmer practice as check), $\mathrm{P}_{2}: 135 \mathrm{~N}+$ $60 \mathrm{P}_{2} \mathrm{O}_{5}+30 \mathrm{~K}_{2} \mathrm{O} \mathrm{kg} \mathrm{ha}{ }^{-1}, \mathrm{P}_{3}: \mathrm{P}_{2}+$ manure $0 \mathrm{tha}^{-1}, \mathrm{P}_{4}: 130$ $\mathrm{N}+60 \mathrm{P}_{2} \mathrm{O}_{5}+60 \mathrm{~K}_{2} \mathrm{O} \mathrm{kg} \mathrm{ha}{ }^{-1}$, and $\mathrm{P}_{5}: \mathrm{P}_{4}+$ manure $10 \mathrm{t}$ $\mathrm{ha}^{-1}$. The subplot was four cassava cultivars consisting of Litbang UK2 $\left(\mathrm{V}_{1}\right)$, UK1 Agritan $\left(\mathrm{V}_{2}\right)$, Malang $4\left(\mathrm{~V}_{3}\right)$, and UJ5 $\left(\mathrm{V}_{4}\right)$. Urea $46 \% \mathrm{~N}$, SP36 $36 \% \mathrm{P}_{2} \mathrm{O}_{5}$, and $\mathrm{KCl} 60 \%$ $\mathrm{K}_{2} \mathrm{O}$ use as the source of $\mathrm{N}, \mathrm{P}$, and $\mathrm{K}$ fertilizer, respectively.

\subsection{Procedure}

The soil was cultivated and mounded before planting. The cutting stems of $20 \mathrm{~cm}$ length were planted in plot measuring of $5 \mathrm{~m} \times 5 \mathrm{~m}$ with planting distance of $1 \mathrm{~m} \times$ $1 \mathrm{~m}$. Phosphorus (P) and $\mathrm{K}$ fertilizer according to the treatments were applied once at 1 mo (month) after planting (MAP), while half dose of $\mathrm{N}$ fertilizer was applied at $1 \mathrm{MAP}$, and the remaining at $3 \mathrm{MAP}$.

\subsection{Data collection and analysis}

Growth variables (plant height and biomass), fresh root yields, yield components (number and weight of fresh root per plant, and harvest index), and starch content (wet base) were recorded at harvest (10 MAP). The plant height was measured from the stem above ground up to the tallest branch of the plant (Gyau 2015; Macalau et al. 2018). The shoot biomass measured based on weight of three plants at 9 mo after the crop was established (Pacheco et al. 2020.
Yield components were observed from three plants (Fukuda et al. 2010). Yield was calculated through destructive harvesting by uprooting and weighing cassava roots from a $25 \mathrm{~m}^{2}$ land area in the farmer's field, and the final yield $\left(\mathrm{t} \mathrm{ha}{ }^{-1}\right)$ calculated through extrapolation (Tarawali et al. 2012). Harvest index was calculated as the ratio of the storage root weight to the total biomass of shoots and storage root (Adjebeng-Danquah et al. 2016; Adu et al. 2020). Starch content was measured according to Fukuda et al. (2010). Red mite (Tetranychus urticae Koch) attacks was recorded during the growth according to Bellotti and Schoonhoven (1978). Observation of mite attack was carried out by scoring on the affected leaves, by giving a score 0 to healthy leaves (no spots), score 1 if there is early yellowish spotting (about $10 \%$ ) on some lower and/or middle leaves, score 2 if there is slightly yellowish spots (11 \% to $20 \%$ ) on lower and middle leaves, score 3 if there is obvious damage; a lot of yellow spots $(21 \%$ to $50 \%)$, few areas are necrotic $(<20 \%)$, especially the lower and middle leaves are slightly wrinkled; some leaves turn yellow and fall off, score 4 if there is severe damage (51\% to $75 \%$ ) on the lower and middle leaves, the mite population is abundant and white threads are found like spider webs, and score 5 if total leaf loss occurs; plant shoots shrink; more and more white thread; plant death.

The collected-data were subjected to statistical analysis of variance (ANOVA) and the means were compared using the $L S D$ test at a $5 \%$ level of significance (Adinurani, 2016)

\section{Result and Discussions}

\subsection{Soil chemical properties}

The soil data indicate that soil fertility is low. The acidic soil $\mathrm{pH}$ with very low $\mathrm{Al}$ might be due to $\mathrm{Ca}$ and $\mathrm{Mg}$ cations leached-out from the top soil layer. Soil $\mathrm{pH}$ is classified as optimum for cassava growth because it is in the optimum soil $\mathrm{pH}$ range for cassava, which is 4.5 to 6.5 , according to Howeler et al. (2019). The soil $\mathrm{pH}$ might not become a major limiting factor for cassava because it is still in the range of the optimum value.

Available $\mathrm{P}$ is medium, but it might become limiting factor because of low soil $\mathrm{pH}$. Under low soil $\mathrm{pH}, \mathrm{P}$ nutrient become less mobile due to $\mathrm{Al}$ or Fe fixation. Soil organic matter content as indicated by C-organic content is below the critical levels of organic matter of $3.2 \%$ according to Howeler (2014), or at least at the critical level of $1.3 \%$ according to Gomes (1998). Organic matter (OM) content is very low, and so that $\mathrm{N}$ content is also very low because $\mathrm{OM}$ is a main source of $\mathrm{N}$ in soil. The soil data indicate that soil fertility is low, and OM, N, P, Ca, and $\mathrm{Mg}$ might become the main constraint for cassava growth and high yield.

\subsection{Growth and yield of four cassava cultivars}

The results of the analysis of variance (ANOVA) showed that the fertilizer factor did not significantly affect all parameters observed, while the cultivars significantly affected all the parameters observed. There is no significant interaction between the two factors, except for plant height (Table 2). The genetic differences among cultivars have more effect on growth, yield, and yield components than fertilizer treatment. 
Table 2. Results of ANOVA on all parameters observed.

\begin{tabular}{|c|c|c|c|c|c|c|c|c|c|}
\hline \multirow[b]{2}{*}{ Factor } & \multicolumn{9}{|c|}{ Mean square value } \\
\hline & $\begin{array}{l}\text { Plant height } \\
\text { (cm) }\end{array}$ & $\begin{array}{l}\text { Shoot weight } \\
\text { plant }^{-1}(\mathrm{~kg})\end{array}$ & $\begin{array}{l}\text { Biomass } \\
\text { plant }^{-1}(\mathrm{~kg})\end{array}$ & $\begin{array}{l}\text { Number of } \\
\text { root plant }^{-1}\end{array}$ & $\begin{array}{l}\text { Root weight } \\
\text { plant }^{-1}(\mathrm{~kg})\end{array}$ & $\begin{array}{l}\text { Root yield } \\
\left(\mathrm{t} \mathrm{ha}^{-1}\right)\end{array}$ & $\begin{array}{l}\text { Harvest } \\
\text { index }\end{array}$ & $\begin{array}{l}\text { Starch content } \\
\text { (\% wb) }\end{array}$ & $\begin{array}{l}\text { Starch yield } \\
\left(\mathrm{t} \mathrm{ha}^{-1}\right)\end{array}$ \\
\hline $\begin{array}{l}\text { Fertilizer } \\
\text { (F) }\end{array}$ & $0.08 \mathrm{~ns}$ & $0.004 \mathrm{~ns}$ & $0.02 \mathrm{~ns}$ & $3.28 \mathrm{~ns}$ & $0.10 \mathrm{~ns}$ & $8.37 \mathrm{~ns}$ & $0.004 \mathrm{~ns}$ & $2.26 \mathrm{~ns}$ & $0.28 \mathrm{~ns}$ \\
\hline Cultivar (V) & $0.11 *$ & $0.035 * *$ & $0.10 * *$ & $5.70 *$ & $3.29 * *$ & $5.81 * *$ & $0.049 * *$ & $26.10 * *$ & $5.13 * *$ \\
\hline $\mathrm{F} \times \mathrm{V}$ & $0.06 *$ & $0.002 \mathrm{~ns}$ & 0.04 & $3.34 \mathrm{~ns}$ & $0.05 \mathrm{~ns}$ & $4.32 \mathrm{~ns}$ & $0.003 \mathrm{~ns}$ & $2.43 \mathrm{~ns}$ & $0.19 \mathrm{~ns}$ \\
\hline CV (\%) & 13.7 & 28.88 & 17.70 & 21.5 & 29.50 & 29.50 & 8.43 & 7.53 & 15.71 \\
\hline
\end{tabular}

Annotation: $\mathrm{ns}=$ not significant, $*=$ significantly different at $5 \%$, ** = significantly different at $1 \%$, wb $=$ wet basis

Soil N, P, and organic matter in the experiment site height at harvest averaged $175.2 \mathrm{~cm}$, biomass were low, but application of N-P-K fertilizer, and also addition of organic fertilizer could not improve cassava growth (Table 3), as well as root yield and yield components (Table 4). The results indicate that fertilizer applied may be ineffective. Cassava in this experiment was planted in January 2018, so that the crop received high rainfall only for 3 mo (January to March), and rainfall decreased from April 2018 (Figure 1). It means that the plants suffer from drought after 3 MAP. The age at 3 MAP to $6 \mathrm{MAP}$ is critical period for cassava because fast growing, root formation, as well as root development take place during that period. Lack of water will limit water absorption, as well as nutrient uptake which reduce crop growth and yield. Under these conditions, production efficiency was low as indicated by low harvest index. Plant accumulation less than $1 \mathrm{~kg}$ plant $^{-1}$ (Table 3), fresh root yield (14.22 to 16.29) $\mathrm{t} \mathrm{ha}^{-1}$, harvest index about 0.6 , and starch content $13.82 \%$ to $15.17 \%$ (Table 4). Decrease in nutrient uptake occured in cassava plants under insufficient soil water (Howeler, 2012), and also reduction of plant height of cassava by $33 \%$ to $47 \%$ (Vitor et al., 2019). Root yield, harvest index, and starch content in this experiment is low. In acidic soil in Lampung with fertilization of $135 \mathrm{~N}+36 \mathrm{P}_{2} \mathrm{O}_{5}+30$ to $60 \mathrm{~K}_{2} \mathrm{O} \mathrm{kg} \mathrm{ha}{ }^{-1}$, UJ3 and UJ5 cultivar at 6 MAP produced (30 to 40) $\mathrm{t} \mathrm{ha}^{-1}$ of fresh root with harvest index 0.7 to 0.8 and starch content $>25 \%$ (Taufiq et al., 2015), and Malang 4 cultivar in East Java produced $>40 \mathrm{tha}^{-1}$ at $10 \mathrm{MAP}$ with harvest index 0.7 to 0.8 and starch content $>26 \%$ (Taufiq et al., 2016).

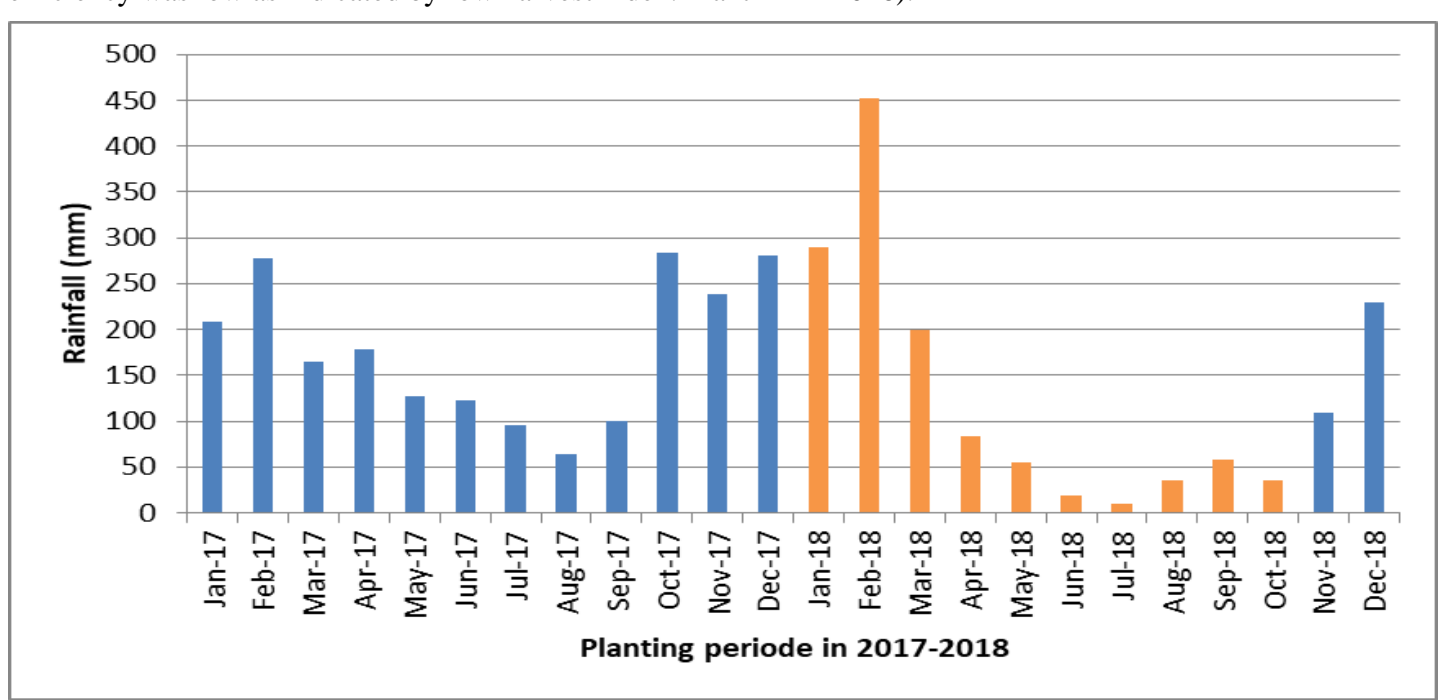

Figure 1. Rainfall in Pati District, Central Java, Indonesia during the experiment (January to October 2018).

Table 3. Effect of fertilizer doses on plant height, shoot weight, and biomass accumulation of cassava crop Pati district, Central Java, Indonesia 2018

\begin{tabular}{llll}
\hline Fertilizer doses & Plant height $(\mathrm{cm})$ & Shoot weight plant $^{-1}(\mathrm{~kg})$ & Biomass weight plant $^{-1}\left(\mathrm{~kg}^{2}\right.$ \\
\hline $\mathrm{P}_{1}$ & 185.8 & 0.24 & 0.99 \\
$\mathrm{P}_{2}$ & 165.8 & 0.21 & 0.89 \\
$\mathrm{P}_{3}$ & 168.6 & 0.22 & 0.89 \\
$\mathrm{P}_{4}$ & 180.0 & 0.20 & 0.91 \\
$\mathrm{P}_{5}$ & 175.9 & 0.25 & 0.95 \\
Average & 175.2 & 0.22 & 0.93 \\
LSD (5\%) & 0.19 & 0.05 & 0.196 \\
\hline
\end{tabular}


Table 4. Effect of fertilizer on root number plant ${ }^{-1}$, root weight plant ${ }^{-1}$, root yield ( $\left.\mathrm{t} \mathrm{ha}^{-1}\right)$, harvest index, starch content (\% wb), and starch yield $\left(\mathrm{t} \mathrm{ha}^{-1}\right)$, in dryland. Pati district, Central Java, Indonesia 2018

\begin{tabular}{|c|c|c|c|c|c|c|}
\hline Fertilizer doses & $\begin{array}{l}\text { Root number } \\
\text { plant }^{-1}\end{array}$ & $\begin{array}{l}\text { Root weight } \\
\text { plant }^{-1}(\mathrm{~kg})\end{array}$ & $\begin{array}{l}\text { Root yield } \\
\left(\mathrm{t} \mathrm{ha}^{-1}\right)\end{array}$ & $\begin{array}{l}\text { Harvest } \\
\text { index }\end{array}$ & $\begin{array}{l}\text { Starch content } \\
\text { (\% wb) }\end{array}$ & $\begin{array}{l}\text { Starch } \\
\text { yield } \\
\left(\mathrm{t} \mathrm{ha}^{-1}\right)\end{array}$ \\
\hline $\mathrm{P}_{1}$ & 7.11 & 1.59 & 14.32 & 0.61 & 14.32 & 2.44 \\
\hline $\mathrm{P}_{2}$ & 8.11 & 1.59 & 14.22 & 0.64 & 13.82 & 2.29 \\
\hline $\mathrm{P}_{3}$ & 7.44 & 1.68 & 15.15 & 0.65 & 14.62 & 2.48 \\
\hline $\mathrm{P}_{4}$ & 7.99 & 1.64 & 14.76 & 0.63 & 14,69 & 2.46 \\
\hline Average & 7.76 & 1.66 & 14.94 & 0.64 & 14.52 & 2.48 \\
\hline LSD (5 \%) & 0.93 & 0.252 & 2.27 & 0.025 & 1.08 & 0.44 \\
\hline
\end{tabular}

The fertilization doses independently did not significantly affect the yield and the components of yield (Table 4). Similar to Pypers et al. (2011), the addition of fertilizer did not influence root yield. But reported by Cuvaca et al. (2017), fertilizer addition increased cassava root yield. Aplication $60 \mathrm{~kg} \mathrm{~N} \mathrm{ha}^{-1}+60 \mathrm{~kg}_{2} \mathrm{O}_{5} \mathrm{ha}^{-1}+0$ $\mathrm{kg} \mathrm{K}_{2} \mathrm{O}$ ha $^{-1}$ increase root yield up to $27.7 \mathrm{t} \mathrm{ha}^{-1}$ compared with no fertilizer aplication. Organic matter utilization could improve root yield and soil fertility (Badewa et al. 2020), but in this study organic matter didn't improve the yield. Although not significantly different, it is seen that the root yield ( $\mathrm{t} \mathrm{ha}{ }^{-1}$ ) in the $\mathrm{P}_{2}$ to $\mathrm{P}_{5}$ fertilizer treatment is higher than the root yield in $\mathrm{P}_{1}$ (farmer control) as well as the harvest index. Highest starch content and starch yield found in $\mathrm{P}_{5}\left(130 \mathrm{~kg} \mathrm{~N} \mathrm{ha}^{-1}+60 \mathrm{~kg} \mathrm{P}_{2} \mathrm{O}_{5} \mathrm{ha}^{-1}+60 \mathrm{~kg} \mathrm{~K}_{2} \mathrm{O}\right.$ $\mathrm{ha}^{-1}+$ manure 10 t.ha $^{-1}$ ) which indicate that increasing $\mathrm{K}$ fertilizer dose and the addition of manure could increase the starch content.

The effect of cultivars on plant height, shoot weight, and total plant weight (without root) were significantly different (Table 5). Plant height ranges from $164.3 \mathrm{~cm}$ to $182.9 \mathrm{~cm}$. UK 1 Agritan grows tallest, while the shortest was Litbang UK 2 compared to the other cultivar. Growth parameters were more influenced by cultivar differences than fertilization treatment. According to Misganaw and Bayou (2020), variations in plant height can occur due to genetic variations. The highest shoot weight was achieved by the UK 1 Agritan variety while the lowest was the Litbang UK 2 cultivar. Likewise, the total plant biomass weight plant ${ }^{-1}$ (without root), the highest weight was achieved by UK 1 Agritan cultivar, and the lowest was UJ 5 cultivar. UJ 5 cultivar had a high shoot weight, but the stem was relatively small, so that the total plant biomass weight was the lowest among the other cultivars (Table 5). This indicates that UK 1 Agritan cultivar has better adaptability compared to the other cultivars.
Table 5. Effect of cultivars on plant height, shoot weight plant ${ }^{-1}$, and biomass weight plant ${ }^{-1}$ in dryland. Pati District, Central Java, Indonesia 2018

\begin{tabular}{|c|c|c|c|}
\hline Cultivars & $\begin{array}{l}\text { Plant height } \\
(\mathrm{cm})\end{array}$ & $\begin{array}{l}\text { Shoot weight } \\
\text { plant }^{-1}(\mathrm{~kg})\end{array}$ & $\begin{array}{l}\text { Biomass weight } \\
\text { plant }^{-1}(\mathrm{~kg})\end{array}$ \\
\hline Litbang UK 2 & $164.3 \mathrm{~b}$ & $0.17 \mathrm{~b}$ & 0.88 bc \\
\hline UK1 Agritan & $182.9 \mathrm{a}$ & $0.27 \mathrm{a}$ & $1.01 \mathrm{a}$ \\
\hline Malang 4 & $173.1 \mathrm{ab}$ & $0.19 \mathrm{~b}$ & $0.98 a b$ \\
\hline UJ 5 & $180.6 \mathrm{a}$ & $0.26 \mathrm{a}$ & $0.84 \mathrm{c}$ \\
\hline Average & 175.2 & 0.22 & 0.93 \\
\hline LSD (5 \%) & 0.13 & 0.05 & 0.12 \\
\hline
\end{tabular}

Note : Mean values in each colum followed by different letters were significantly different $(P<0.05)$.

The interaction between fertilizer doses and cultivar only significantly affected plant height. The highest plant height was achieved in the $P_{3} V_{2}$ treatment $(195.0 \mathrm{~cm})$, while the lowest was in the $\mathrm{P}_{2} \mathrm{~V}_{1}$ treatment which was $140.7 \mathrm{~cm}$ (Figure 2). It can be seen that the UK 1 Agritan $\left(\mathrm{V}_{2}\right)$ variety which has good plant growth, plant height increased with the treatment $\mathrm{P}_{3}\left(135 \mathrm{~N}+60 \mathrm{P}_{2} \mathrm{O}_{5}+30\right.$ $\mathrm{K}_{2} \mathrm{O} \mathrm{kg} \mathrm{ha}{ }^{-1}+$ manure $10 \mathrm{t} \mathrm{ha}^{-1}$ ). This indicates that the plant height of UK 1 Agritan didn't require the addition of $\mathrm{K}$ nutrients because the soil had high $\mathrm{K}$ nutrient, even the addition of $\mathrm{K}$ actually reduced plant height as shown in treatment $\mathrm{P}_{4}$ and $\mathrm{P}_{5}$.

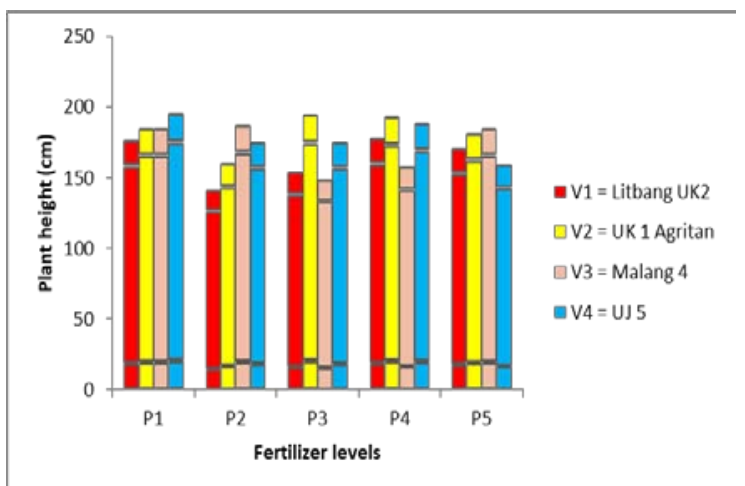

Figure 2. Effect of fertilization and cultivars on cassava plant height at $10 \mathrm{mo}$. Pati district, Central Java, Indonesia 2018. $\left(\mathrm{P}_{1}=\right.$ $275 \mathrm{~N}+45 \mathrm{P}_{2} \mathrm{O}_{5}+45 \mathrm{~K}_{2} \mathrm{O}, \mathrm{P}_{2}=135 \mathrm{~N}+60 \mathrm{P}_{2} \mathrm{O}_{5}+30 \mathrm{~K}_{2} \mathrm{O} \mathrm{kg}$ ha $^{-1}, \mathrm{P}_{3}=\mathrm{P}_{2}+$ manure $10 \mathrm{tha}^{-1}, \mathrm{P}_{4}=130 \mathrm{~N}+60 \mathrm{P}_{2} \mathrm{O}_{5}+60 \mathrm{~K}_{2} \mathrm{O} \mathrm{kg}$ ha ${ }^{-1}$, and $\mathrm{P}_{5}=\mathrm{P}_{4}+$ manure $10 \mathrm{tha}^{-1}$ ). 
Cultivars showed significant differences in yield and yield components, namely the root number plant ${ }^{-1}$, root weight plant $^{-1}$, root yield $\mathrm{ha}^{-1}$, harvest index, starch content, and starch yield ha ${ }^{-1}$ (Table 6). These suggested that among varieties used, there were potential genetic differences.

The highest root number plant ${ }^{-1}$ was found in UJ 5 cultivar, but it was not significantly different with UK 1 Agritan cultivar. The smallest root number plant $^{-1}$ was found in Malang 4. Likewise, the highest root weight plant $^{-1}$ and the highest root yield ha ${ }^{-1}$ was in UK 1 Agritan cultivar, and the lowest was in the Litbang UK 2 cultivar. UK 1 Agritan was a cassava cultivar released in 2016 with early maturity characters. Based on farmers' information, UK 1 Agritan was quite preferred as a choice besides UJ 5 because it has not only high yield potential but also plant posture was not too large, with white root skin color. UK 1 Agritan also had a high harvest index (HI). HI is one indicator to estimate root yield. Harvest index were positively correlated $\left(\mathrm{r}=0.61^{* *}\right)$ with root yield, so that the higher harvest index will have higher root yields. Karim et al. (2020) also found positive correlation between root yield and $\mathrm{HI}$. The HI is variable to measure the efficiency of storage root production (Badewa et al., 2020). UJ 5 cultivar had the highest starch content followed by Malang 4 and Litbang UK 2, and the lowest was UK 1 Agritan (Table 6). Even though it has the lowest starch content, UK 1 Agritan has the highest root yield and hence the higher starch yield $\mathrm{ha}^{-1}$.

Table 6. Effect of cultivar on root number, plant weight, root yield, harvest index, starch content, and starch yield in dryland. Pati district, Central Java, Indonesia 2018

\begin{tabular}{|c|c|c|c|c|c|c|}
\hline Cultivars & $\begin{array}{l}\text { Root } \\
\text { number } \\
\text { plant }^{-1}\end{array}$ & $\begin{array}{l}\text { Root } \\
\text { weight } \\
\text { plant }^{-1} \\
(\mathrm{~kg})\end{array}$ & $\begin{array}{l}\text { Root } \\
\text { yield } \\
\left(\mathrm{t} \mathrm{ha}^{-1}\right)\end{array}$ & $\begin{array}{l}\text { Harvest } \\
\text { index }\end{array}$ & $\begin{array}{l}\text { Starch } \\
\text { content } \\
\text { (\% wb) }\end{array}$ & $\begin{array}{l}\text { Starch } \\
\text { yield } \\
\left(\mathrm{t} \mathrm{ha}^{-1}\right)\end{array}$ \\
\hline Litbang & & & & $0.57 \mathrm{c}$ & $16.88 \mathrm{~b}$ & $1.76 \mathrm{~d}$ \\
\hline UK 2 & $7.07 \mathrm{c}$ & $1.16 \mathrm{c}$ & $10.45 \mathrm{c}$ & & & \\
\hline UK1 & & & & $0.70 \mathrm{a}$ & 15.17 c & $3.10 \mathrm{a}$ \\
\hline Agritan & $8.11 \mathrm{ab}$ & $2.29 \mathrm{a}$ & 20.57 a & & & \\
\hline Malang 4 & $7.43 \mathrm{bc}$ & $1.53 \mathrm{~b}$ & $13.77 \mathrm{~b}$ & $0.61 \mathrm{~b}$ & $16.52 \mathrm{~b}$ & $2.29 \mathrm{c}$ \\
\hline UJ 5 & $8.41 \mathrm{a}$ & $1.67 \mathrm{~b}$ & $14.99 \mathrm{~b}$ & $0.67 \mathrm{a}$ & 18.38 a & $2.76 \mathrm{~b}$ \\
\hline Average & 7.76 & 1.66 & 14.95 & 0.64 & 16.74 & 2.48 \\
\hline LSD & & & & 0.036 & 0.95 & 0.29 \\
\hline$(5 \%)$ & 0.97 & 0.18 & 1.66 & & & \\
\hline
\end{tabular}

Red mite pests commonly attack cassavas in the dry season. A red mite score, that was observed in the $3^{\text {rd }}$ mo, was between 7.35 to $18.57 . \mathrm{P}_{1} \mathrm{~V}_{3}$ treatment showed the lowest attack, and the highest in $\mathrm{P}_{3} \mathrm{~V}_{3}$ treatment (Table 7). Fertilization treatment $\mathrm{P}_{3}$ and $\mathrm{P}_{5}$ had a higher mite attack score than the other treatments. It seems that the addition of organic matter can increase $\mathrm{N}$ nutrition, which causes plant tissue to become softer and it is easily attacked by mites. Altieri et al (2005) stated that an increase of $\mathrm{N}$ nutrient results in increased plant damage due to mites attack. Howeler et al. (2013) stated that application soil organic matter early in the cropping cycle, increases pestregulating populations. To prevent more severe damage from mite attacks, spraying using Starban insecticides is carried out.
Table 7. Red mite pests population in cassava at 3 MAP.

\begin{tabular}{llllll}
\hline \multirow{2}{*}{ Treatment } & \multicolumn{5}{l}{ Mite score (\%) } \\
& V1 & V2 & V3 & V4 & Average \\
\hline P1 & 10.44 & 7.44 & 7.35 & 9.19 & 8.61 \\
P2 & 12.57 & 8.36 & 12.03 & 6.93 & 9.97 \\
P3 & 16.41 & 9.36 & 18.57 & 10.70 & 13.81 \\
P4 & 11.50 & 11.55 & 11.48 & 9.69 & 11.05 \\
P5 & 13.80 & 13.90 & 14.34 & 13.98 & 14.01 \\
Average & 12.94 & 10,12 & 12.75 & 9.50 & \\
\hline
\end{tabular}

\section{Conclusions}

Reducing $\mathrm{N}$ fertilizer dosage from $275 \mathrm{~kg} \mathrm{~N}^{-1}$ to (130 to 135) $\mathrm{kg} \mathrm{N} \mathrm{ha}^{-1}$ and $\mathrm{K}$ from $45 \mathrm{~K}_{2} \mathrm{O} \mathrm{ha}{ }^{-1}$ to $30 \mathrm{~kg}$ $\mathrm{K}_{2} \mathrm{O}$ ha $^{-1}$, increasing $\mathrm{P}$ dosage from $45 \mathrm{P}_{2} \mathrm{O}_{5} \mathrm{ha}^{-1}$ to 60 $\mathrm{P}_{2} \mathrm{O}_{5} \mathrm{ha}^{-1}$, and application of $10 \mathrm{tha}^{-1}$ manure has no effect on both cassava growth and yield. Agronomic and yield performance of UK 1 Agritan cultivar is better than Litbang UK 2, Malang 4, and UJ 5 cultivars, and hence can be recommended as an alternative cultivar for farmers in the Pati area, Central Java, Indonesia. But the increase in $\mathrm{N}$ nutrient increases the attack of mite pests.

\section{References}

Adjebeng-Danquah J, Gracen VE, Offei SK, Asante IK, and Manu-Aduening J. 2016. Genetic variability in storage root bulking of cassava genotypes under irrigation and no irrigation. Agric. Food Secur, 5(9):1-12.

Adinurani, P.G. 2016. Design and Analysis of Agro Trial Data: Manual and SPSS. Plantaxia, Yogyakarta, Indonesia.

Adinurani PG, Rahayu S, Purbajanti ED, Siskawardani DD, Stankeviča K, and Setyobudi RH. 2021. Enhanced of root nodules, uptake NPK, and yield of peanut plant (Arachis hypogaea L.) using rhizobium and mycorrhizae applications. Sarhad J. Agric. 37 (Special Issue 1): 16-24.

Adu MO, Asare PA, Yawson DO, Nyarko MA, Razak AA, Kusi AK, Tachie-Menson JW, Afutu E, Andoh DA, Ackah FK, Vanderpuije GC, Taah KJ, Bediako EA, and Amenorpe G. 2020. The search for yield predictors for mature field-grown plants from juvenile pot-grown cassava (Manihot esculenta Crantz). PLoS One 15(5)e0232595:1-27.

Altieri MA, Nicholls CI, and Fritz M. 2005. Manage Insects on Your Farm: A Guide to Ecological Strategies. Sustainable Agriculture Research and Education - Handbook Series; bk. 7.

Badewa OD, Saba AG, Tsado EK, and Tolorunse KD. 2020. Selection of early bulking performance among pro vitamin A cassava genotypes based on selective indices of fresh storage root yield and harvest index. International Journal of Genetics and Genomics 8(1):11-18.

Bellotti AC and Schoonhoven AV. 1978. Cassava Pests and Their Control. Centro Internacional de Agricultura Tropical (CIAT), Cali, Columbia.

Biratu GK, Elias E, Ntawuruhunga P, and Sileshi GW. 2018. Cassava response to the integrated use of manure and npk fertilizer in Zambia. Heliyon 4(00759) :1-23.

BPS Jawa Tengah. 2016. Harvested area, production, and productivity of cassava by Regency / City in Central Java Province, 2012-2015. from

https://jateng.bps.go.id/dynamictable/2020/01/10/653/luas-panenproduksi-dan-produktivitas-ubi-kayu-menurut-kabupaten-kota-diprovinsi-jawa-tengah-2012-2015.html (Accessed on August 19th 2020]. 
Budiono R, Adinurani PG, and Peeyush S. 2019. Effect of new NPK fertilizer on lowland rice (Oryza sativa L.) growth. IOP Conf Ser Earth Environ Sci., 293(012034):1-10.

Budiono R, Aziz FN, Purbajanti ED, Turkadze T, and Adinurani PG. 2021. Effect and effectivity of granular organic fertilizer on growth and yield of lowland rice. E3S Web Conf., 226(00039):1-7.

Cuvaca IB, Eash NS, Lambert DM, Walker FR, and Rustrick W. 2017. Nitrogen, phosphorus, and potassium fertilizer effects on cassava root yield in the coastal district of Dondo, Mozambique. Afr. J. Agric. Res 12(42):3112-3119.

Ezui KS, Franke AC, Mando A, Ahiabor BDK, Tetteh FM, Sogbedji J, and Giller KE. 2016. Fertilizer requirements for balanced nutrition of cassava across eight locations on West Africa. Field Crops Res. 185: 69-78.

Fukuda WMG, Guevara CL, Kawuki R, and Ferguson ME. 2010. Selected Morphological and Agronomic Descriptors for the Characterization of Cassava. International Institute of Tropical Agriculture (IITA), Ibadan, Nigeria.

Gyau GB. 2015. Evaluation of growth, yield and root quality of four (4) cassava (Manihot esculenta Crantz) varieties in the semideciduous zone of Ghana. MSc Dissertation, Kwame Nkrumah University of Science and Technology, Kumasi, Ghana.

Hiironen J and Riekkinen K. 2016. Agricultural impact and profitability of land consolidations. Land Use Policy 55:309-317.

Howeler RH. 2002. Cassava Mineral Nutrition and Fertilization. In: Hillocks RJ, Thresh JM, Bellotti AC (Eds.), Cassava: Biology, Production and Utilization. CAB International, pp. 115-147.

Howeler RH. 2012. Dry matter accumulation and nutrient absorption and distribution during the growth cycle of cassava. In: Howeler RH (Ed.) Chapter 14, The Cassava Handbook: A Reference Manual Based on the Asian Regional Cassava Training Course held in Thailand. Centro Internacional de Agricultura Tropical (CIAT) Cassava Office for Asia, Bangkok, Thailand. pp 351-410.

Howeler RH, Lutaladio NB, and Thomas G. 2013. Crop nutrition. In: Gutiérrez D (Ed.), Chapter 5- Save and Grow: Cassava, A Guide to Sustainable Production Intensification. Food and Agriculture Organization of the United Nations, Rome. pp 59-72.

Howeler RH. 2014. Sustainable Soil and Crop Management of Cassava in Asia- Cali, CO : Centro Internacional de Agricultura Tropical (CIAT). - (CIAT Publication No. 389)

Howeler RH. 2017. Does cassava cultivation degrade or improve the soild? Proc. 8th Regional Workshop A New Future for Cassava in Asia: Its Use as Food, Feed and Fuel to Benefit the Poor. Vientiane, Lao PDR. pp 320-354.

Howeler RH, Oates CG, and Allem AC. 2019. An Assessment of the impact of cassava production and processing on the environment and biodiversity. Strategic environmental assessment (fao.org).

Karim KY, Ifie B, Dzidzienyo D, Danquah EY, Blay ET, Whyte JBA, Kulakow P, Rabbi I, Parkes E, Omoigui L, Norman PE, and Iluebbey P. 2020. Genetic characterization of cassava (Manihot esculenta Crantz) genotypes using agro-morphological and single nucleotide polymorphism markers. Physiol Mol Biol Plants 26: 317-330.

Li Q, Xu M, Liu G, Zhao Y, and Tuo D. 2013. Cumulative effects of a 17-years chemical fertilization on the soil quality of cropping system in the loess hilly region China. J. Plant. Nutr. Soil Sci .176(2):249-259.
Macaloua S, Mwongab S, and Musanduc A. 2018. Performance of two cassava (Manihot escculenta Crantz) genotypes to NPK fertilizer in Ultisols of Sikasso Region, Int. J. Sci. Basic Appl. Res. 38(2): 189-206.

Magdoff F and van Es Harold. 2021. What is organic matter and why is it so important. In: Magdoff $\mathrm{F}$ and van Es Harold (Eds) Chapter 2. Building Soils for Better Crops. Sustainable Agriculture Research and Education. College of Agriculture and Natural Resources, University of Maryland, USA. 394p.

Misganaw CD and Bayou WD. 2020. Root yield and yield component performance of cassava (Manihot esculenta) varieties in Fafen Disrict, Ethiopia. Int. J. Agron. (5836452): 1-6.

Muhammad M., Umi I, Peeyush S, and Praptiningsih GA. 2021. Effectiveness of mycorrhiza, plant growth promoting rhizobacteria and inorganic fertilizer on chlorophyll content in Glycine $\max$ (L.) cv. Detam-4 Prida. E3S Web Conf., 226(00031):1-8.

Noerwijati K and Budiono R. 2015. Yield and yield components evaluation of cassava (Manihot esculenta Crantz) clones in different altitudes. Energy Procedia 65:155-161.

Pacheco RI, Macias MP, Campos FC, Izquierdo AJ, and Izquierdo GA. 2020. Agronomic and physiological evaluation of eight cassava clones under water deficit conditions. Revista Facultad Nacional De Agronomía Medellín, 73(1): 9109-9119.

Pypers P, Sanginga JM, Kasereka B, Walangululu M, and Vanlauwe B. 2011. Increased productivity through integrated soil fertility management in cassava-legume intercropping systems in the highlands of Sud-Kivu, DR Congo. Field Crops Res., 120(1): 76-85.

Tarawali G, Iyangbe C, Udensi UE, Ilona P, Osun T, Okater C, and Asumugha GN. 2012. Commercial-scale adoption of improved cassava varieties: A baseline study to highlight constraints of large-scale cassava based agro-processing industries in Southern Nigeria. Journal of Food, Agriculture \& Environment, 10 (3\&4): 689-694. 2012.

Taufiq A, Subandi, and Suyamto H. 2015. Response of Cassava (Manihot esculenta Crantz.) to potassium application on acidic dryland in Indonesia. International Potash Institute e-ifc 42:18-26.

Taufiq A, Subandi, and Suyamto H. 2016. Response of Cassava (Manihot esculenta Crantz.) to potassium application on various soil types in East and Central Java, Indonesia. International Potash Institute e-ifc 45:19-30.

Utami SNH, Abduh AM, Hanudin E, and Purwanto BH. 2020. Study on the NPK uptake and growth of rice under two different cropping systems with different doses of organic fertilizer in the Imogiri Subdistrict, Yogyakarta province, Indonesia. Sarhad J. Agric. 36(4): 1190-1202.

Van der Velde M, Folberth C, Balkovič J, Ciais P, Fritz S, Janssens IA, and Jeñuelas J. 2014. African crop yield reductions due to increasingly unbalanced Nitrogen and Phosphorus comsumption. Glob. Change Biol. 20(4):1278-1288.

Vitor AB, Diniz RP, Morgante CV, Antônio RP, and de Oliveira EJ. 2019. Early prediction models for cassava root yield in different water regimes. Field Crops Res, 239:149-158.

Wahyuningsih S and Sutrisno. 2019. Growth and productivity of several cassava varieties with different level of fertilizers in young teak field. Buletin Palawija 17(1):40-45.

Yasmin F, Othman R, and Maziz MNH. 2020. Yield and nutrient content of sweet potato in response of plant growth-promoting rhizobacteria (PGPR) inoculation and $\mathrm{N}$ fertilization. Jordan $J$ Biol Sci., 13(1):117-122. 